\title{
THE AGE OF THE ILIVERTALIK GRANITE IN THE FISKENÆSSET AREA
}

\author{
R. T. Pidgeon, M. Aftalion and F. Kalsbeek
}

\section{Introduction}

The Ilivertalik granite has been briefly described by Kalsbeek \& Myers (1973). It forms the mountain of Ilivertalik north-west of Midgård and consists mainly of a very homogeneous, relatively coarse grained brownish-weathering, hypersthene-bearing augen gneiss of granitic composition.

The object of this paper is to present the results of a zircon $\mathrm{U}-\mathrm{Pb}$ geochronological study of the granite and to discuss the significance of the results in terms of the regional geology and previous geochronology.

\section{Geological relationships of the granite}

The emplacement of the Ilivertalik granite represents an important time point in the history of the Archaean in this region. As described by Kalsbeek \& Myers (1973) the granite intrudes foliated and migmatized amphibolite and streaky gneiss which themselves locally contain inclusions of rocks of the anorthosite complex. Following emplacement the granite has been strongly deformed during the second and third phases of folding recognised in this part of the area. It possesses steeply plunging linear fabrics $\left(F_{2}\right.$ or $\left.F_{3}\right)$ and near the bordering gneisses it may be strongly foliated. The Ilivertalik granite of Ilivertalik mountain has a hornblende granulite facies mineralogy. Comparable rocks farther to the north and north-east are in amphibolite facies. Locally the Ilivertalik granite is migmatized and cut by sheets of younger granite.

\section{The zircon sample}

The investigated sample was supplied as a zircon concentrate by F. Kalsbeek. The sample was further purified at the S.U.R.R.C. to greater than 98 percent zircon. It was then subdivided into a number of size and magnetic fractions and selected fractions were boiled for approximately ten minutes in 1:1 nitric acid and then in distilled water and were then isotopically analysed. Analytical methods followed those of Krogh (1973). Isotopic analyses were made on the AEIGEC MS 12 mass-spectrometer at the S.U.R.R.C.

The zircons are subhedral with irregular rounded and embayed facets. Many grains contain transparent and opaque rod shaped inclusions. Faint euhedral zones have been observed in many crystals suggesting that the zircons grew as euhedral crystals and that late chemical corrosion produced the present irregular forms. A few oval shaped grains, up to a maximum of five percent, resemble zircons described from the gneiss and tonalite of the Frederikshåb area (Jocelyn \& Pidgeon, 1974) and might be xenocrysts. A few examples of 'parallel growth' described by these authors for zircons from the gneisses and tonalites were found in the Ilivertalik granite zircon population. 
Table 2. U-Pb isotopic analyses of zircon fractions from Ilivertalik granite sample GGU 131124

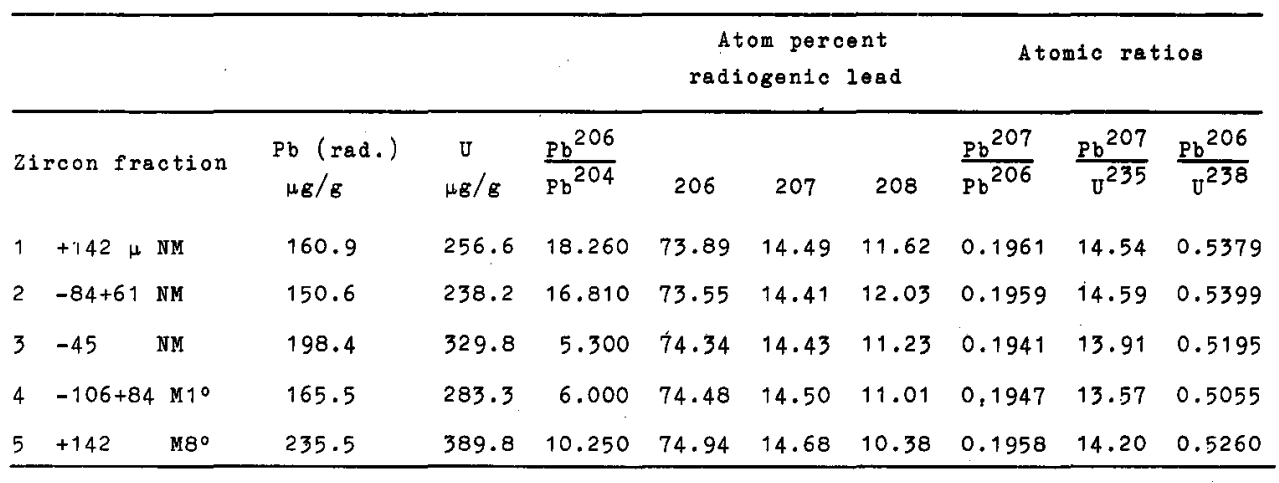

Calculated with the following constants $\mathrm{U}^{235} / \mathrm{U}^{238}-1 / 137.8, \lambda \mathrm{U}^{238}=1.53 \times 10^{-10} \mathrm{y}^{-1}$, $\lambda \mathrm{U}^{235}=9.72 \times 10^{-10} \mathrm{y}^{-1}$

Common lead correction $\mathrm{Pb}^{206} / \mathrm{Pb}^{204}=18.1, \mathrm{~Pb}^{207} / \mathrm{Pb}^{204}=15.5, \mathrm{~Pb}^{208} / \mathrm{Pb}^{204}=36.5$

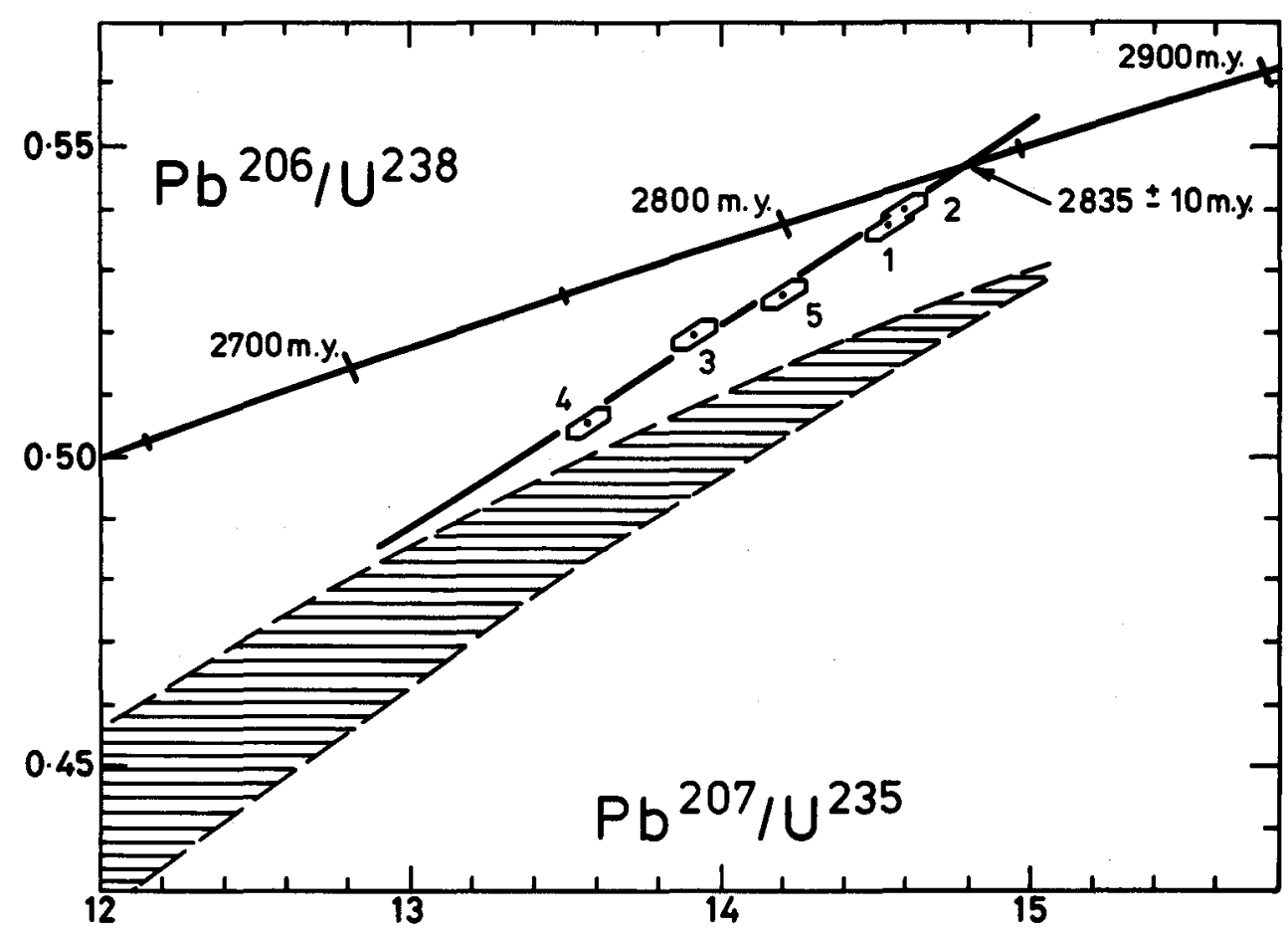

Fig. 16. Section of a concordia plot showing the linear distribution of the five data-points. Error polygons were calculated using an uncertainty of \pm 0.2 percent in $\mathrm{Pb}^{207} / \mathrm{Pb}^{206}$ and \pm 0.5 percent in $\mathrm{Pb} / \mathrm{U}$. The shaded area contains zircon data-points from gneisses and tonalites from near the Frederikshåbs Isblink (reported by Pidgeon \& Hopgood, 1975). 


\section{The isotopic age determination}

$\mathrm{U}-\mathrm{Pb}$ isotopic analyses of five fractions from a single zircon population (from sample number GGU 131124) are shown on Table 2 and plotted on figure 16.

It can be seen from the reported atomic ratios that the zircons are slightly discordant. It is shown on fig. 16 that the zircon points fall on a line slightly below the concordia curve. On extrapolation this line intersects the concordia at $2835 \pm 10$ m.y. (The error is a visual estimate of the maximum uncertainty of the intersection). This result is independent of whether a model of 'episodic lead loss' or 'lead loss by slow continuous diffusion' is used to explain the slight isotopic discordance.

\section{Discussion and conclusions}

The distribution of discordant zircon data-points from the gneiss and tonalite from near the Frederikshåbs Isblink (Pidgeon \& Hopgood, 1975) is shown as a shaded area on fig. 16. The U-Pb systems of these zircons are complex. Pidgeon \& Hopgood interpret them as indicating a minor component of pre-2900 m.y. old lead in the zircons, which was almost completely removed during a major isotopic disturbance approximately $2700 \mathrm{~m} . \mathrm{y}$. ago. These zircon isotopic relationships were further complicated by a recent isotopic disturbance which produced the present discordant pattern.

The linear distribution and close concordance of the Ilivertalik granite zircon points (fig. 16) indicates that the granite zircon U-Pb systems do not contain significant components of lead contributed by 'older' gneiss zircons.

We conclude therefore that $2835 \pm 10 \mathrm{~m} . \mathrm{y}$. is the age of crystallization of zircon during emplacement of the Ilivertalik granite.

The zircon U-Pb age of the Ilivertalik granite of $2835 \pm 10$ m.y. is not significantly different from the $\mathrm{Pb}-\mathrm{Pb}$ whole-rock age of $2850 \pm 100$ m.y. reported by Black et al. (1973) for gneisses and anorthosites from the Nordland - Sukkertoppen and Fiskenæsset areas. These authors interpret the $\mathrm{Pb}-\mathrm{Pb}$ age as that of the regional granulite facies metamorphism. This is in accord with the geological evidence that emplacement of the Ilivertalik granite took place fairly late in the plutonic history of the area, and perhaps during the waning stages of the granulite facies metamorphism of the Fiskenæsset region. If this is so the time interval between $F_{2}$ (which deforms the granite) and the granulite facies metamorphism (which continued post- $\mathrm{F}_{3}$ ) must have been short. The alternative possibility that the zircon age reflects the granulite facies metamorphism of the granite without retaining any memory of an older age is considered less likely.

\section{References}

Black, L. P., Moorbath, S., Pankhurst, R. J. \& Windley, B. F. 1973: ${ }^{207} \mathrm{~Pb} /{ }^{206} \mathrm{~Pb}$ whole rock age of the Archaean granulite facies metamorphic event in West Greenland. Nature phys. Sci. 244, $50-53$.

Jocelyn, J. \& Pidgeon, R. T. 1974: Examples of twinning and parallel growth in zircons from some Precambrian granites and gneisses. Mineralog. Mag. 39, 587-94.

Kalsbeek, F. \& Myers, J. S. 1973: The geology of the Fiskenæsset region, South-West Greenland. Rapp. Grønlands geol. Unders. 51, 5-18.

Krogh, T. E. 1973: A low-contamination method for hydrothermal decomposition of zircon and extraction of $\mathrm{U}$ and $\mathrm{Pb}$ for isotopic age determinations. Geochim. cosmochim. Acta 37, 485-494.

Pidgeon, R. T. \& Hopgood, A. M. 1975: Geochronology of Archaean gneisses and tonalites from north of the Frederikshåbs isblink, S. W. Greenland. Geochim. cosmochim. Acta, 39, 1333-1346. 